\title{
Role of foliar fungal endophytes in litter decomposition among species and population origins
}

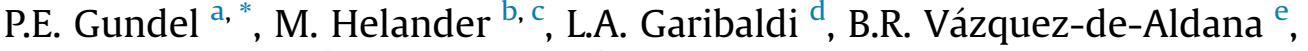 \\ I. Zabalgogeazcoa ${ }^{\mathrm{e}}$, K. Saikkonen ${ }^{\mathrm{C}}$ \\ a IFEVA, CONICET, Faculty of Agronomy, Buenos Aires University (UBA), Argentina \\ b Section of Ecology, Department of Biology, University of Turku, 20100 Turku, Finland \\ ${ }^{\mathrm{c}}$ Natural Resources and Biomass Production Research, Natural Resources Institute Finland (Luke), 20520 Turku, Finland \\ ${ }^{\mathrm{d}}$ Grupo de Investigación en Agroecología (AGRECO), Sede Andina, Universidad Nacional de Río Negro (UNRN) and Consejo Nacional de Investigaciones \\ Científicas y Técnicas (CONICET), Mitre 630, CP 8400 San Carlos de Bariloche, Río Negro, Argentina \\ e Department of Abiotic Stress, Instituto de Recursos Naturales y Agrobiología de Salamanca (IRNASA), Consejo Superior de Investigaciones Científicas \\ (CSIC), Salamanca, Spain
}

\section{A R T I C L E I N F O}

\section{Article history:}

Received 28 December 2015

Received in revised form

29 February 2016

Accepted 8 March 2016

Available online 20 April 2016

Corresponding editor: James White Jnr

\section{Keywords:}

Epichloë

Festuca spp.

Symbiosis

Plant-microorganism interaction

Ecosystem processes

\begin{abstract}
A B S T R A C T
Litter decomposition is a key ecosystem process which returns nutrients from dead plant material to mineral forms in the soil. We examined whether systemic fungal endophytes modulate recycling of nutrients directly by altering litter decomposition. We studied litter decomposition mediated by Epichloë endophytes in litter-bag experiments. We examined direct endophyte effects on litter decomposition in wild populations and cultivars of Schedonorus phoenix and Schedonorus pratensis. In the first experiment, endophyte presence tended to increase litter decomposition rate in cultivars of the two grass species (S. phoenix and S. pratensis). However, in the second experiment plant origin had a stronger influence than endophyte symbiosis in S. phoenix. Interestingly, the initial level of alkaloids was associated positively with decomposition in S. phoenix populations. Characteristics associated with litter quality were not clearly related to either endophytes or decomposition rate. Our results suggest that endophytes can enhance litter breakdown but their role in nutrient cycling is far more complex depending on plant population origin.
\end{abstract}

() 2016 Elsevier Ltd and British Mycological Society. All rights reserved.

\section{Introduction}

Decomposition is a key process for ecosystem functioning as it releases nutrients from dead organic material into mineral forms, thus controlling nutrient cycling and energy flow (Chapin et al., 2002). Decomposition affects the soil carbon budget, a critical aspect related to global change and climate warming (Wardle et al., 2004). Climate, the quality of litter biomass and the community composition of decomposer organisms are all important factors affecting decomposition (Aerts, 1997). While temperature and humidity explain variation at regional scales, biomass quality and decomposer assemblages can govern decomposition rates at local scales (Zhang et al., 2008; Austin et al., 2014; Karhu et al., 2014).

\footnotetext{
* Corresponding author. IFEVA, CONICET, Department of Ecology, Faculty of Agronomy, Buenos Aires University (UBA), Av. San Martín 4453, C1417DSE Ciudad de Buenos Aires, Argentina.
}

E-mail address: gundel@agro.uba.ar (P.E. Gundel).
Although microbes are well recognized players in decomposition, the impact of symbiotic organisms, such as plant-associated endophytic fungi, on the process has received little attention (Purahong and Hyde, 2011; Saikkonen et al., 2015). These plant symbionts may affect decomposition through different pathways; they can act as saprobionts in senescencing dead plant materials, but they can also enhance or inhibit the processes by modulating the soil community decomposers through changes in the quality of plant tissues for detritivores.

Virtually all plant leaves are colonized by endophytic fungi, which live internally and asymptomatically within host tissues (Saikkonen et al., 1998; Rodriguez et al., 2009). The majority of these fungi belong to a taxonomically heterogeneous pool of nonsystemic endophytes, whose ecological roles are largely unresolved (Saikkonen, 2007; Higgins et al., 2011; Zabalgogeazcoa et al., 2013; Saikkonen et al., 2015). In contrast to non-systemic fungi, some vertically transmitted fungal endophytes form persistent symbioses with their grass hosts and by having strong ecological 
and evolutionary consequences, alter host phenotypic traits (Saikkonen et al., 1998; Clay and Schardl, 2002; Gundel et al., 2010). Studies on function of symbiosis between Pooideae grasses and epichloid fungi (Clavicipitaceae, Hypocreales, Ascomycota) have mostly focused on the bio-protective role of fungal alkaloids against herbivores and pathogens (Clay and Schardl, 2002; Schardl et al., 2007; Saikkonen et al., 2013a). Other ecological effects, including negative effects on decomposers, have been more recently ascribed to these fungal derived compounds (Omacini et al., 2004; Lemons et al., 2005; Siegrist et al., 2010). Besides producing alkaloids, these fungal endophytes may directly affect other plant traits involved in decomposition (Omacini et al., 2004; Gundel et al., 2012; Hamilton et al., 2012; Saikkonen et al., 2015).

Endophytes can modify the phenotype of their host grasses including traits such as the carbon/nitrogen ratio ( $\mathrm{C}: \mathrm{N}$ ratio), phosphorus level, and fiber content of foliage (Lyons et al., 1990; Rasmussen et al., 2008; White and Torres, 2010; Rogers et al., 2011; Hamilton et al., 2012; Vázquez-de-Aldana et al., 2013a) which can directly affect litter decomposition (Berendse et al., 1987; Güsewell and Gessner, 2009; Hall and Silver, 2013). However, past attempts to understand the effects of endophyte symbiosis on these traits and consequently on decomposition, have been inconclusive. Actually, a recent meta-analysis which included all the published papers so far, failed to find an overall significant inhibitory effect of endophytes on the litter decomposition of host grasses (Omacini et al., 2012). In addition to endophyte presence, the plant traits related to litter decomposition depend on host plant genotype, plant ontogenic stage, and grazing history (Burns et al., 2006; Rogers et al., 2011; Jia et al., 2014).

Here we examined the effect of endophyte presence on litter decomposition of two grass species, Schedonorus phoenix (formerly Festuca arundinacea Schreb., and common name: tall fescue) and Schedonorus pratensis (formerly Festuca pratensis Huds., and common name: meadow fescue) using litter-bag experiments in a common garden. In accordance with the general tendency of endophytes affecting negatively the decomposition of litter (see review by Omacini et al., 2012), we predicted that endophyte symbiosis would slow down mass loss. As a test of the relative importance of endophyte symbiosis, we manipulated endophyte presence interactively with plant population (tall fescue: three wild origins and one cultivar 'Kentucky-31'; meadow fescue: cultivar 'Kasper'), given the expectation that litter decomposition would vary with plant genotypes (see Madritch and Hunter, 2004).

\section{Materials and methods}

\subsection{Plant material}

The endophyte symbiotic (E+) and non-symbiotic (E-) plant material used in the two litter-bag experiments was collected from $S$. phoenix and $S$. pratensis plants grown in a common garden at Ruissalo Botanical Garden (University of Turku, Finland). The S. phoenix plant populations were originally collected from three geographic locations around the Baltic Sea, Åland, (Finland), Gotland and Södermanland (Sweden). In addition to these three wild plant populations, one commercial cultivar, 'Kentucky-31', was included in the study. Ten individual plants of each origin and symbiotic status were placed at random in a grid with $1 \mathrm{~m}^{2}$ for each plant in 2005 (Gundel et al., 2013a,b). In an adjacent plot and following a similar design, ten individual plants of S. pratensis (cultivar 'Kasper'), symbiotic and non-symbiotic with endophyte were planted in 2008 (Saikkonen et al., 2013b). In all cases, the endophyte-free plants were obtained by treating symbiotic seeds with heated water before sowing to kill the fungus, and confirming the symbiotic status before planting the plants in the common garden. In the years following plant establishment in the common garden, their symbiotic status was confirmed by checking for the endophyte presence or absence in the seeds produced by symbiotic and non-symbiotic plants, respectively, under light microscope (for details see Gundel et al., 2013a,b; and Saikkonen et al., 2013b).

In autumn 2011, biomass from the 10 plants from each combination of species, population origin, and symbiotic status were harvested and air dried. Dried leaf and pseudostem biomass were enclosed in litter-bags ( $4 \pm 0.05 \mathrm{~g} / \mathrm{bag} ; 1 \mathrm{~mm}^{-2}$ mesh, $10 \times 14 \mathrm{~cm}$ size). Two experiments were set up in an enclosure at Ruissalo Botanical Garden, and prior to that, the natural grassland vegetation was removed and soil was superficially homogenized to avoid spatial variation in microbial community.

\subsubsection{Experiment 1. Effects of grass species and endophyte symbiosis}

The experiment tested the effects of the endophyte symbiosis (E+ and $\mathrm{E}-$ ) and species identity (S. phoenix and S. pratensis) on litter decomposition. There were 160 litter-bags from the combination of 2 grass species (S. phoenix cultivar 'Kentucky-31' and S. pratensis cultivar 'Kasper') and two endophyte statuses (E-, E+). The bags were established in a grid where each place for each bag (experimental unit) was randomly assigned, at a distance of $20 \mathrm{~cm}$ from each other, and anchored with $10 \mathrm{~cm}$ nails to the ground. The litter-bag experiment corresponded to a full factorial design with 10 replicates and 4 retrieval times. Ten randomly selected bags from each treatment combination were retrieved on four dates: June and September 2012, and May and September 2013. The decomposition rate was determined by weighing the remaining oven dried litter biomass in the bags.

\subsubsection{Experiment 2. Effects of plant origin and endophyte symbiosis}

The experiment tested the effect of endophyte symbiosis ( $\mathrm{E}+$ and $\mathrm{E}-$ ) and three wild population origins (Åland, Gotland, Södermanland) and one cultivar (Kentucky-31) of $S$. phoenix on litter decomposition. A total of 320 bags from the two endophyte statuses $(\mathrm{E}+, \mathrm{E}-)$ and four plant origins (three wild origins and one cultivar) were placed on a grid where each litter-bag was $20 \mathrm{~cm}$ apart from each other. Similar to experiment 1 , the experiment corresponded to a full factorial design with 10 replicates and 4 retrieval times. The four retrieval dates were exactly the same as before. Decomposition was determined by weighing the remaining oven dried litter biomass in each bag.

\subsection{Chemical analyses of the litter}

Mineral composition (Ca, Cu, Fe, Mg, Mn, N, K, P, S, Zn), carbon content $(C)$, acid detergent fiber (ADF), acid detergent lignin (ADL) and fungal origin alkaloids (ergovaline and peramine) were analyzed at the beginning of the experiments, from three randomly selected litter bags per host species, host origins, and endophyte status.

Mineral composition was determined by the ICP-OES (inductively coupled plasma optical emission spectrometry) method. Samples were digested in concentrated nitric acid $(10 \mathrm{ml})$ and evaporated into about $1-2 \mathrm{ml}$. The sample was then transferred into a $50 \mathrm{ml}$ volumetric flask, diluted with MILLI-Q purified water, and filtered before the ICP-OES measurement. Mineral and trace elements were measured by high resolution ICP-OES (Perkin Elmer Optina 8300) (Kumpulainen and Paakki, 1987). One blind and 1-3 reference samples were included in each sample batch. Carbon and nitrogen were determined with an automated dry combustion method (Dumas method) by Leco TruMac $\mathrm{CN}$ - analyzer, Leco Corporation, USA.

Acid detergent fiber [ADF: cellulose + lignin + ash (minerals and silica)] and acid detergent lignin (ADL: lignin) were determined 
Table 1

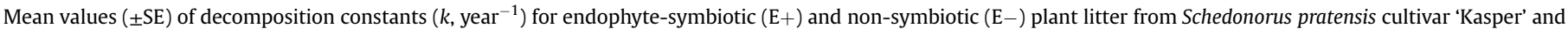

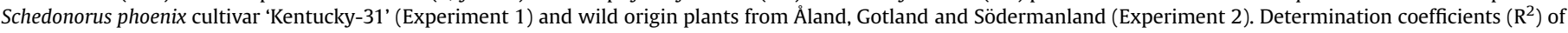
the fitted linear models relating the remaining mass in litter-bags [ln(Mt/M0)] and experimental time (t) for each combination of population by endophyte status.

\begin{tabular}{|c|c|c|c|c|c|c|}
\hline \multirow[t]{2}{*}{ Species } & \multirow[t]{2}{*}{ Population } & \multirow[t]{2}{*}{ Endophyte } & \multicolumn{2}{|c|}{ Experiment 1} & \multicolumn{2}{|c|}{ Experiment 2} \\
\hline & & & $k$ & $\mathrm{R}^{2}$ & $k$ & $\mathrm{R}^{2}$ \\
\hline \multirow[t]{2}{*}{ Schedonorus pratensis } & \multirow[t]{2}{*}{ 'Kasper’ } & $\mathrm{E}+$ & $0.65(0.05)$ & 0.81 & & \\
\hline & & $\mathrm{E}-$ & $0.64(0.05)$ & 0.77 & & \\
\hline \multirow[t]{8}{*}{ Schedonorus phoenix } & \multirow[t]{2}{*}{ 'Kentucky-31' } & $\mathrm{E}+$ & $0.65(0.05)$ & 0.77 & $0.59(0.04)$ & 0.79 \\
\hline & & $\mathrm{E}-$ & $0.64(0.04)$ & 0.82 & $0.59(0.04)$ & 0.84 \\
\hline & \multirow[t]{2}{*}{ Åland } & $\mathrm{E}+$ & & & $0.62(0.03)$ & 0.87 \\
\hline & & $\mathrm{E}-$ & & & $0.66(0.04)$ & 0.85 \\
\hline & \multirow[t]{2}{*}{ Gotland } & $\mathrm{E}+$ & & & $0.56(0.04)$ & 0.83 \\
\hline & & $\mathrm{E}-$ & & & $0.53(0.04)$ & 0.80 \\
\hline & \multirow[t]{2}{*}{ Södermanland } & $\mathrm{E}+$ & & & $0.62(0.05)$ & 0.78 \\
\hline & & $\mathrm{E}-$ & & & $0.64(0.04)$ & 0.85 \\
\hline
\end{tabular}

using the filter bag technique, with an Ankom Automated Fiber Analyzer A2000, based on the analytical method of Goering and Van Soest (1970).

To determine the levels of fungal-produced alkaloids, ergovaline and its isomer ergovalinine were quantified by HPLC following a modification of the methods described by Hill et al. (1993) and Yue et al. (1997). A $500 \mathrm{mg}$ litter sample was extracted in $1 \mathrm{ml}$ of $\mathrm{CHCl}_{3}$ and $0.5 \mathrm{ml}$ of $0.5 \mathrm{mM} \mathrm{NaOH}$ for $2 \mathrm{~h}$ in an orbital shaker. One hundred microliters of an internal standard solution of ergotamine ditartrate (10 $\mu \mathrm{g} \mathrm{ml}^{-1}$, Sigma-Aldrich) were added to the sample prior to extraction. The mixture was filtered through Whatman $\mathrm{n}^{\circ} 2$ filter paper and the filtrate was passed through a $500 \mathrm{mg}$ Ergosil (Analtech; Newark, USA) solid-phase column preconditioned with $\mathrm{CHCl}_{3}$. Plant pigments were removed with $5 \mathrm{ml}$ of chloroform:acetone (1:3). The sample was eluted with $2 \mathrm{ml}$ of methanol and vacuum concentrated, redissolved in $1 \mathrm{ml}$ of methanol, and filtered through a $0.22 \mu \mathrm{m}$ nylon filter. Extracts were chromatographed with a Waters 2690 system with an Xterra MS C18 Waters column $(4.6 \times 100 \mathrm{~mm} ; 3.5 \mu \mathrm{m})$. The initial solvent gradient was $35 \%$ acetonitrile in $0.01 \mathrm{M}$ ammonium acetate buffer $(\mathrm{pH}=7.6$ ), with a flow rate of $0.8 \mathrm{ml} \mathrm{min}{ }^{-1}$. The gradient was adjusted through time programming as follows: step 1, 35\%-50\% acetonitrile in a 20 min linear gradient; step 2, 50\% for 5 min; step 3, 50\%-90\% in a 5 min linear gradient; step $4,90 \%-35 \%$ in a 5 min linear gradient. Ergovaline and its isomer were detected by fluorescence spectrophotometry with an excitation wavelength of $250 \mathrm{~nm}$ and an emission wavelength of $420 \mathrm{~nm}$ (Waters Fluorescent Detector 2475). Ergovaline and ergovalinine areas were combined, and the total was reported as ergovaline.

The endophyte alkaloid peramine was determined using the HPLC method described by Barker et al. (1993) and Yue et al. (2000). A freeze-dried and ground sample (100 mg) of plant material was extracted in $3 \mathrm{ml}$ of $30 \%$ isopropanol for $30 \mathrm{~min}$ at $90^{\circ} \mathrm{C}$. The mixture was centrifuged and the extract was passed through a pre-conditioned Varian Bond Elut carboxylic acid (CBA) column packed with $100 \mathrm{mg}$ of adsorbent. After a wash of the column with $1-2 \mathrm{ml}$ of methanol, peramine was eluted with $1 \mathrm{ml}$ of $5 \%$ formic acid in $80 \%$ aqueous methanol. The extract was filtered through a $0.22 \mu \mathrm{m}$ nylon filter and chromatographed in a Waters 2690 system with a Nova Pak C18 Waters column $(3.9 \times 150 \mathrm{~mm} ; 4 \mu \mathrm{m})$. The isocratic mobile phase consisted of $18 \%(\mathrm{v} / \mathrm{v})$ acetonitrile in a guanidine carbonate $(10 \mathrm{mM})$-formic acid buffer. Detection was performed with a Photodiode Array Detector (PDA) Waters 2996 set at $280 \mathrm{~nm}$

\subsection{Statistical analysis}

For responses of litter decomposition in experiment 1, we used a general linear model to evaluate the effects of plant endophyte symbiotic status (two levels: E+ or E-), species (two levels: S. phoenix or S. pratensis), time (four levels: days of decomposition), and all their interactions on litter mass ( $\mathrm{g}$ ). For experiment 2, we estimated a general linear model to evaluate the effects of plant infection status (two levels: $\mathrm{E}+$ or $\mathrm{E}-$ ), plant population (four levels: Åland, Gotland, Södermanland, or 'Kentucky-31'), time (four levels: days of decomposition), and all their interactions on litter mass ( $\mathrm{g}$ ). Model assumptions were met in all cases (note that different litter bags were harvested at different times, so there is no temporal pseudo-replication). The models for the analysis of these two experiments did take into account the four dates of retrieval.

Litter decomposition rates were estimated by calculating the decay constant $k$, as the slope of a single exponential model for each combination of plant origin and endophyte symbiosis (Wieder and Lang, 1982): $\ln (\mathrm{Mt} / \mathrm{M} 0)=\mathrm{y}-k \mathrm{t}$, where $\mathrm{M} 0$ and $\mathrm{M} t$ represent the initial litter mass and the mass remaining at time $t$ (yr), respectively. The $k$ values were obtained by least-squares regression using all replicates per litter type for each date. Regression analyses for estimating the $\mathrm{k}$ values included the litterbag mass at time 0 (a common starting point in $4 \mathrm{~g}$ for all the populations).

To quantify responses of litter quality, we first used a principal component analysis including all foliar traits, namely dry matter,

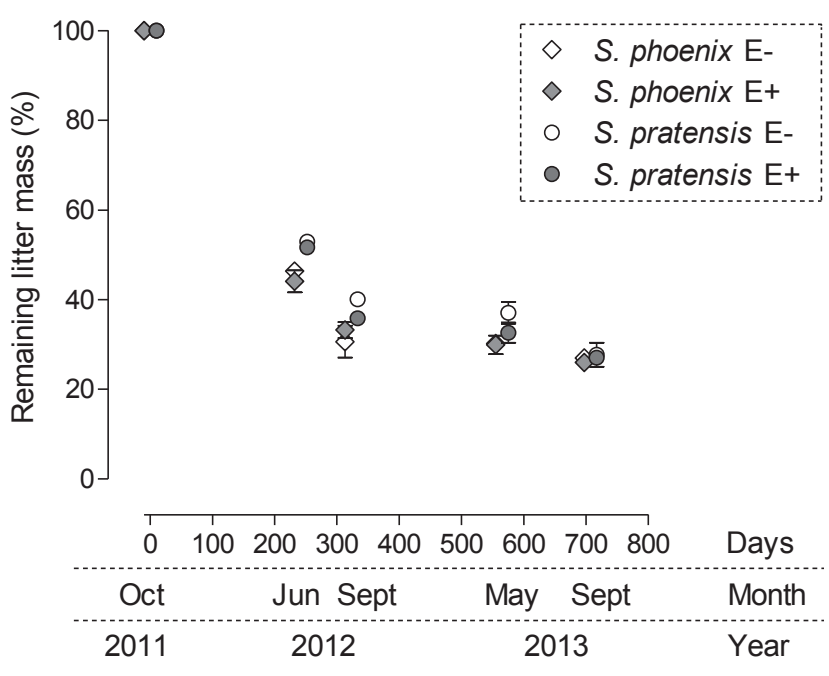

Fig. 1. Litter biomass loss (remaining litter mass, \%) of Schedonorus phoenix cultivar 'Kentucky-31' (diamond) and Schedonorus pratensis cultivar 'Kasper' (circles) symbiotic (E+, dark symbols) or non-symbiotic ( $\mathrm{E}-$, open symbols) with fungal endophyte during a 3 yr experiment. Values are means and the bars indicate standard error $(n=10)$. Symbols belonging to different species are displaced to avoid overlapping. 


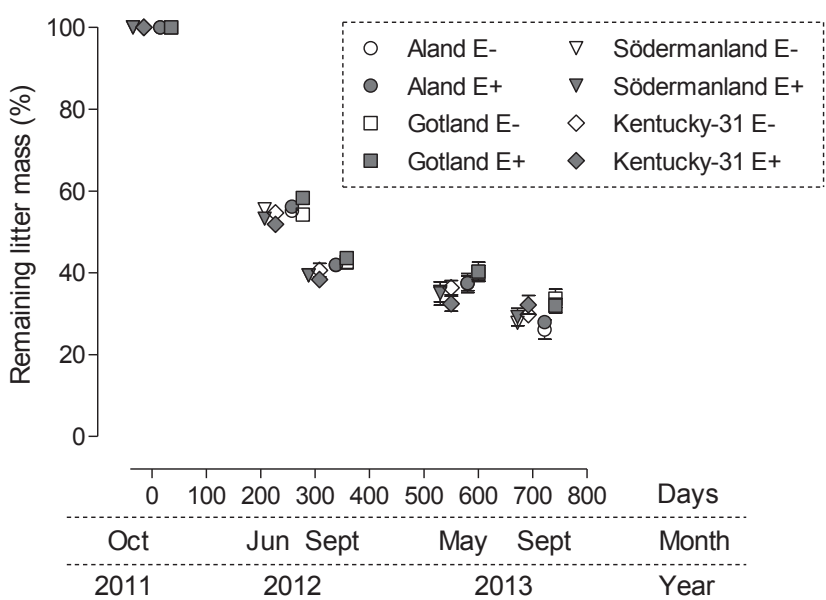

Fig. 2. Litter biomass loss (remaining litter mass, \%) of Schedonorus phoenix plants from different origins: Åland (circles), Gotland (squares), Södermanland (triangles) and cultivar 'Kentucky-31' (diamond) symbiotic (E+, dark symbols) and non-symbiotic (E-, open symbols) with fungal endophyte during a $3 \mathrm{yr}$ experiment. Values are means and the bars indicate standard error $(n=10)$. Symbols belonging to different origin are displaced to avoid overlapping.

ash, ADF, ADL, and concentrations of N, C, Ca, Cu, Fe, K, Mg, Mn, P, S, and $\mathrm{Zn}$. Then, we applied a general linear model to evaluate the effects of the endophyte status of plant (two levels: E+ or E-), plant origins (5 levels: S. pratensis and the four origins of S. phoenix), and their interactions on the scores of the first principal component (PCA1). The same model was estimated for the scores of the PCA2, and for N, C and C:N (see Supplementary material). The same information about each of the foliar traits individually is provided in (Gundel et al., 2016; see Table 1, Figs. 1 and 2). In all cases, inference was performed through analysis of variance (ANOVA), for which assumptions were met. All analyses were performed in R Software, version 3.0.2 (R Development Core Team, 2013). The $\mathrm{lm}$ function of the base package was employed for general linear models, the lme function of the nlme package (Pinheiro et al., 2014) for general linear mixed-effects models, and the prcomp function of the base package for principal component analyses ( $R$ Development Core Team, 2013).

\section{Results}

\subsection{Experiment 1. Effects of grass species and endophyte symbiosis}

Biomass loss over time $\left(F_{3}=119.969, P<0.001\right)$ depended on the grass species $\left(F_{1}=25.635, P<0.001\right)$ and the endophyte symbiotic status of litter $\left(F_{1}=4.912, P=0.028\right)$ (Table S1; Fig. 1$)$. The greatest biomass loss was detected during the first year (Fig. 1). In this period, the biomass loss of $S$. phoenix was greater than that of S. pratensis (60\% vs. 54\%), and the overall decomposition rate of endophyte symbiotic biomass was higher than that of endophyte free biomass ( $59 \%$ vs. 56\%) but the difference leveled off by the end of the experiment (Fig. 1). However, differences between species was not reflected by the estimated $k$ values whereas it was slightly higher for endophyte-symbiotic litter than for endophyte-free litter (Table 1).

\subsection{Experiment 2. Effects of plant origin and endophyte symbiosis}

The litter biomass loss of $S$. phoenix depended on the origin of plants $\left(F_{3}=9.355, P<0.001\right)$ irrespective of the endophyte symbiotic status $\left(F_{1}=0.002, P=0.959\right)$ (Table S2; Fig. 2$)$. At the end of the experiment, losses of litter biomass were $73 \%, 71 \%, 69 \%$, and 67\% for Åland, Södermansland, 'Kentucky-31', and Gotland, respectively (Fig. 2). Similarly, mean values of $k$ (averaging both symbiotic status for each population) followed the same order being $0.64,0.63,0.59$ and 0.54 , for Åland, Södermansland, 'Kentucky-31', and Gotland, respectively (Table 1).

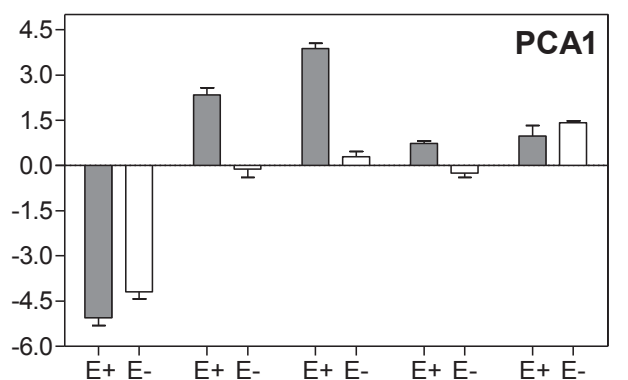

\begin{tabular}{lcc}
\hline & PCA1 & PCA2 \\
\hline K & $\mathbf{0 . 3 6}$ & -0.08 \\
$\mathrm{~S}$ & $\mathbf{0 . 3 4}$ & 0.21 \\
$\mathrm{P}$ & $\mathbf{0 . 3 2}$ & 0.06 \\
$\mathrm{~N}$ & 0.29 & 0.18 \\
Ash & 0.27 & $\mathbf{0 . 3 2}$ \\
Dry matter & 0.25 & -0.07 \\
$\mathrm{Mg}$ & 0.15 & $\mathbf{0 . 4 1}$ \\
$\mathrm{ADL}$ & -0.05 & 0.24 \\
$\mathrm{Ca}$ & -0.08 & $\mathbf{0 . 4 9}$ \\
$\mathrm{Cu}$ & -0.12 & $\mathbf{0 . 4 2}$ \\
$\mathrm{Zn}$ & -0.23 & 0.28 \\
Fe & -0.26 & 0.07 \\
ADF & -0.27 & 0.12 \\
$\mathrm{C}$ & -0.28 & -0.14 \\
$\mathrm{Mn}$ & $-\mathbf{0 . 3 2}$ & 0.20 \\
\hline
\end{tabular}

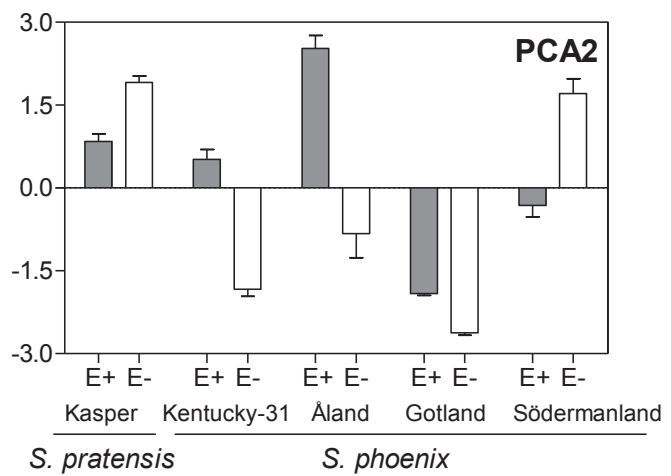

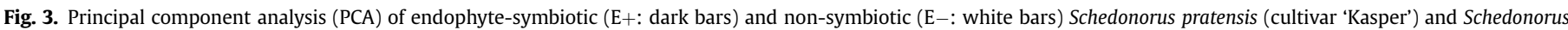

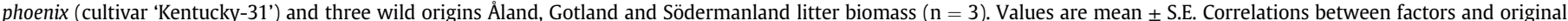

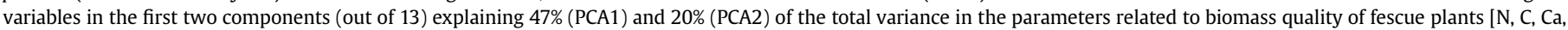

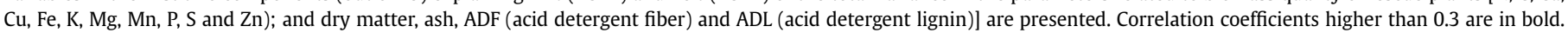



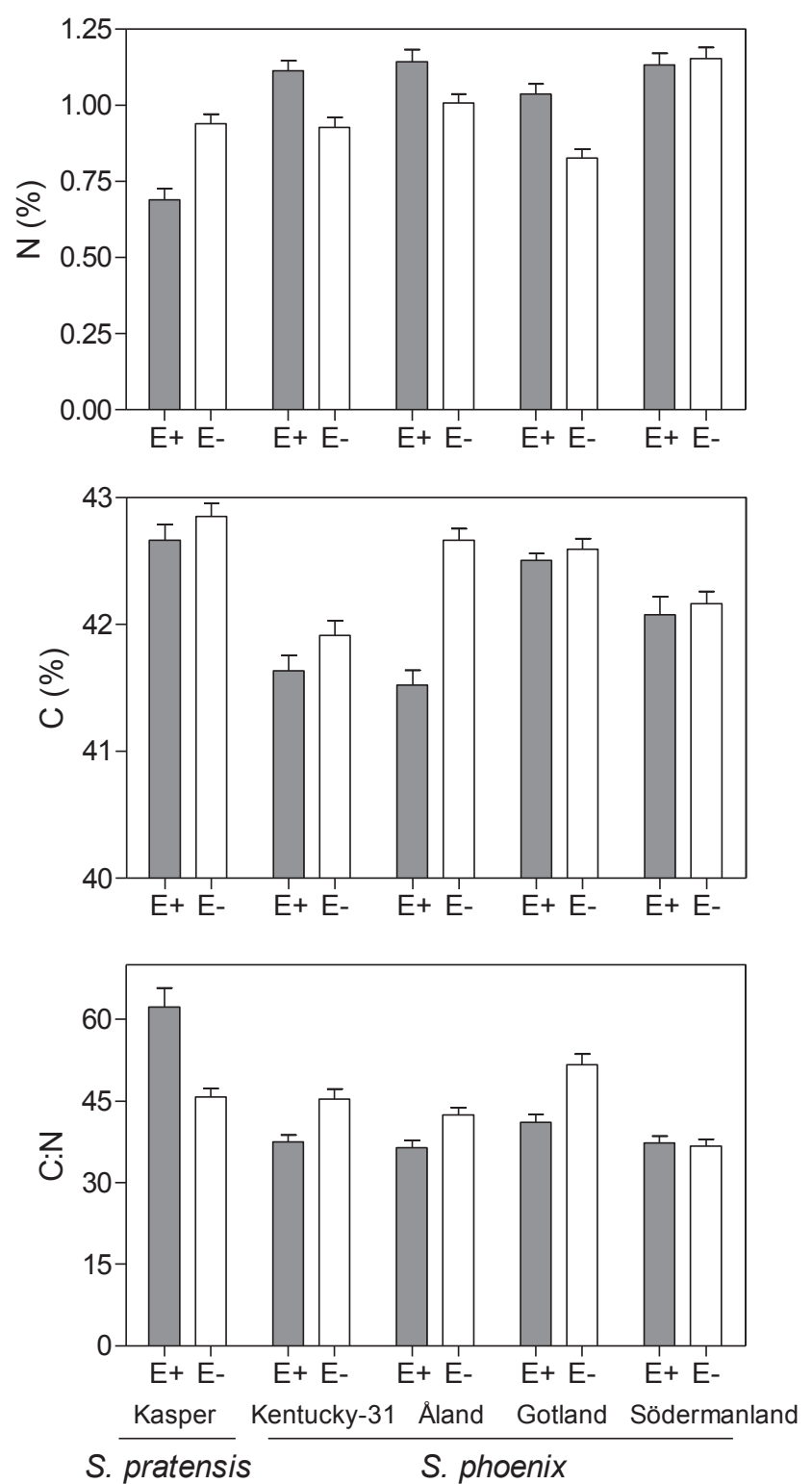

Fig. 4. Nitrogen (N), carbon $(C)$ and $C: N$ ratio in endophyte-symbiotic (E+: dark bars) and non-symbiotic (E-: white bars) fescue plant litter from Schedonorus pratensis (cultivar 'Kasper') and Schedonorus phoenix (cultivar 'Kentucky-31') and three wild origins Åland, Gotland and Södermanland). Values are means \pm S.E $(\mathrm{n}=3)$.

\subsection{Characterization of the litter quality}

The two main principal components of the multivariate analysis explained $67 \%$ of total variation (PCA1: 47\%, and PCA2: 20\%) (Fig. 3). PCA1 was associated with increases in litter $K(0.36), S(0.34)$ and $P$ (0.32), and decreases in litter Mn (-0.32). PCA2 was associated with higher levels of litter $\mathrm{Ca}(0.49), \mathrm{Cu}(0.42), \mathrm{Mg}(0.41)$, and ash (0.32). The two PCA axes were found to be dependent on the two-way interaction between grass origin and endophyte symbiosis (Table S3). Scores in PCA1 seemed to differentiate grass species (S. phoenix vs. S. pratensis) and showed a tendency to separate symbiotic status on S. phoenix (E+ higher than E-). Scores in PCA2 were less clear although a difference between symbiotic statuses (E+ higher than $\mathrm{E}-$ ) was evident in the two cultivars of both species (Fig. 3).

Grass origin and endophyte symbiosis interactively affected the nitrogen and carbon content of litter as well as the C: $\mathrm{N}$ ratio at the beginning of the experiments (Table S3). While the nitrogen content was higher in E+ litter of S. phoenix (except in the case of Södermanland origin litter), carbon tended to be higher in endophyte-free plants in all plant origins (Fig. 4). The $\mathrm{C}: \mathrm{N}$ ratio was lower in $\mathrm{E}+$ than in $\mathrm{E}$ - plants and mirrored the high $\mathrm{N}$ content observed in three of the S. phoenix origins: 'Kentucky-31', Åland and Gotland (Fig. 4). In contrast, S. pratensis E+ litter had higher C:N ratio than E- litter.

Neither of the alkaloids tested at the beginning of the experiment (i.e. peramine and ergovaline) were found in endophyte free populations (Table 2). These two alkaloids were also absent from endophyte-symbiotic plants of $S$. pratensis cultivar 'Kasper'. Endophyte-symbiotic plants of S. phoenix contained both peramine and ergovaline. While plants from Åland and Södermanland had higher levels of both alkaloids relative to plants from the 'Kentucky31' cultivar, Gotland plants had the lowest levels (Table 2).

\section{Discussion}

Contrary to our expectations based on past literature (Omacini et al., 2004; Lemons et al., 2005; Siegrist et al., 2010), endophyte symbiosis did not slow the rate of litter decomposition. Instead, a slightly positive association between the endophyte presence and higher litter mass loss was evident for both studied grass species (cultivars) across the three years of experiment. In the case of S. phoenix, plant origin overrode the effects of endophyte symbiosis. Interestingly, despite the endophyte having a neutral effect on litter decomposition among populations of $S$. phoenix, there was an overall association between initial level of alkaloids and decomposition rate in $\mathrm{E}+$ populations.

We expected that endophyte origin alkaloids that are known to deter herbivores and plant pathogens may affect other leaf endophytes and modulate the soil microbial community and thus, affect litter decomposition of host plants (Matthews and Clay, 2001; Omacini et al., 2004; Lemons et al., 2005; Zabalgogeazcoa et al., 2013). However, our results did not support this hypothesis. In the first experiment which compared endophyte effect in two different species, specifically two cultivars, litter from endophytesymbiotic plants decomposed faster than that from E- plants, and fungal alkaloids appeared not to play a role in limiting the decomposition of litter. Although endophyte-symbiotic S. pratensis plants did not produce any of the alkaloids checked in this study (i.e. peramine or ergovaline), $\mathrm{E}+$ plants of this species are known to produce lolines with demonstrated negative effects on arthropods (Schardl et al., 2007; Patchett et al., 2011). In the second experiment in which the endophyte effect was evaluated in different populations of $S$. phoenix, the symbiont did not have an effect but, interestingly, the level of alkaloids among populations at the beginning of the study was positively correlated with litter mass losses. This was reflected in the percentage of litter losses at the end of the experiment and in the decomposition constants ( $k$ values). In other words, the higher the level of peramine and ergovaline alkaloids were, the higher the observed decomposition rate was. For example, endophyte-symbiotic plants from Åland and Södermanland that lost $73 \%(k=0.62)$ and $71 \%(k=0.62)$ of litter mass during the experiment presented initially the highest levels of peramine ( $3.69 \mu \mathrm{g} \mathrm{g}^{-1}$ and $3.43 \mu \mathrm{g} \mathrm{g}^{-1}$, respectively) and ergovaline (2.79 $\mu \mathrm{g} \mathrm{g}^{-1}$ and $2.80 \mu \mathrm{g} \mathrm{g}^{-1}$, respectively) alkaloids, whereas 'Kentucky-31' and Gotland plants lost 69\% $(k=0.59)$ and $67 \%$ $(k=0.56)$ of litter mass and presented the lowest levels of the alkaloids (peramine: $2.14 \mu \mathrm{g} \mathrm{g}^{-1}$ and $1.69 \mu \mathrm{g} \mathrm{g}^{-1}$, and ergovaline: $2.09 \mu \mathrm{g} \mathrm{g}{ }^{-1}$ and $1.22 \mu \mathrm{g} \mathrm{g}^{-1}$, for 'Kentucky-31' and Gotland, respectively). Taken all together, our results are more in line with those by Siegrist et al. (2010) suggesting that there is not a clear-cut relationship between the alkaloid production of endophytes and 
Table 2

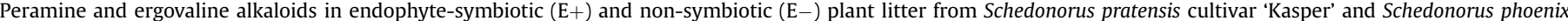

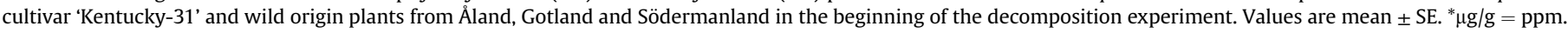

\begin{tabular}{|c|c|c|c|c|}
\hline Species & Population & Endophyte & Peramine $(\mu \mathrm{g} / \mathrm{g})^{*}$ & Ergovaline $(\mu \mathrm{g} / \mathrm{g})^{*}$ \\
\hline \multirow[t]{2}{*}{ Schedonorus pratensis } & ‘Kasper’ & $\mathrm{E}+$ & 0 & 0 \\
\hline & & $\mathrm{E}-$ & 0 & 0 \\
\hline \multirow[t]{8}{*}{ Schedonorus phoenix } & 'Kentucky-31' & $\mathrm{E}+$ & $2.137(0.147)$ & $2.059(0.225)$ \\
\hline & & $\mathrm{E}-$ & 0 & 0 \\
\hline & Åland & $\mathrm{E}+$ & $3.696(0.032)$ & $2.797(0.096)$ \\
\hline & & $\mathrm{E}-$ & 0 & 0 \\
\hline & Gotland & $\mathrm{E}+$ & $1.689(0.020)$ & $1.224(0.002)$ \\
\hline & & $\mathrm{E}-$ & 0 & 0 \\
\hline & Södermanland & $\mathrm{E}+$ & $3.432(0.065)$ & $2.800(0.188)$ \\
\hline & & E- & 0 & 0 \\
\hline
\end{tabular}

the decomposition of dead plant material because alkaloid concentrations decrease in dead standing plant material in a relatively short time. However, as nitrogen-rich compounds (Schardl et al., 2007; Saikkonen et al., 2013a), the alkaloids could, at least in certain cases, contribute to prime the decomposition process.

In addition to endophyte origin alkaloids, endophytes and other microbes can affect many other plant traits that are important controls of litter decomposition (Berendse et al., 1987; Aerts, 1997; Güsewell and Gessner, 2009; Purahong and Hyde, 2011; Omacini et al., 2012; Austin et al., 2014; Karhu et al., 2014; Moorhead et al., 2014; Saikkonen et al., 2015). Our results revealed that endophytes alter the quality of litter in terms of chemical profiles in a very complex way. The lack of overall endophyte main effect across S. phoenix origins may be due to the counter-effect of the symbiont on parameters of the litter that are associated with fast versus slow decomposition. For example, in three plant origins ('Kentucky-31', Åland and Gotland), the endophyte increased three parameters associated with higher rate of decomposition [e.g. high $\mathrm{N}$ (lower $\mathrm{C}: \mathrm{N}$ ) and P], but it also increased ADL (lignin) which slows the decomposition rate (lignin) (Berendse et al., 1987). In Södermanland origin, the endophyte diminished the content of lignin in the litter, but it did not affect the $\mathrm{C}: \mathrm{N}$ ratio and reduced phosphorous. In the first experiment, lignin was lower but $\mathrm{N}$ and $\mathrm{P}$ were higher in S. phoenix cultivar 'Kentucky-31' than in S. pratensis cultivar 'Kasper', potentially explaining the higher decomposition rate of 'Kentucky-31'. The positive effects of $\mathrm{N}$ and $\mathrm{P}$, and the negative effects of lignin on decomposing microorganisms has been extensively documented (Berendse et al., 1987; Güsewell and Gessner, 2009). In addition, we consistently detected higher concentrations of Fe in E+ plants, a key nutrient that, when released from the litter may play a role in the decomposition process (see Hall and Silver, 2013). Our results show that the chemical ecology of endophytes mediating host litter decomposition is complex and remains to be solved in future studies.

The underlying ecological mechanisms, by which the epichloid fungal endophytes enhance or hinder the decomposition process of the host, need to be studied in more detail. Ecological pathways by which the endophytes are likely to affect the decomposition of plant litter and soil nutrient transformations are by affecting the abundance, richness and composition of decomposer organisms, and by affecting the amount and/or quality of the plant litter (Omacini et al., 2014; Saikkonen et al., 2015). It has been recently proposed that Epichloë endophytes may act as saprotrophs aiding the decay of abscised plant parts (Saikkonen et al., 2015). In addition, plants harbor a variable number of non-systemic fungi that have been proposed to be latent saprobes and they could also be controlled by the presence of Epichloë (Zabalgogeazcoa et al., 2013). These microorganisms that are already in the plant tissue before senescence and death are a source of enzymes (e.g. protease, cellulase) that start the decomposition process by attacking the different organic and cell wall components (cellulose, hemicellulose and lignin) (Thormann et al., 2003; Vázquez-de-Aldana et al., 2013b; Austin et al., 2014). Together with the proven impact of endophytes on species richness and diversity of plant communities (see Clay and Holah, 1999; Clay et al., 2005; Rudgers et at., 2010; Saikkonen et al., 2013) and soil biota (Franzluebbers et al., 1999; Casas et al., 2011; Vázquez-de-Aldana et al., 2011; Omacini et al., 2012; Roberts and Ferraro, 2015), we suggest that experimental approaches focusing on the potential role of endophytes as saprotrophs and/or as modulators of the association of plants with latent saprobes, are needed to reveal the ecological pathways through which the endophyte may alter the ecosystem processes.

\section{Acknowledgments}

We thank Serdar Dirihan (University of Turku) for his assistance in the field and the Lab, and Amador Alvarez (IRNASA, Spain) for his assistance in the alkaloid analysis. We also thank Dr. Jennifer A. Rudgers (Department of Biology, University of New Mexico) and Dr. A. Austin (IFEVA, Agronomy College, University of Buenos Aires/ CONICET) for reading and making comments on an early version of the manuscript. This project was funded by Academy of Finland grants 213401 and 209210, Turku University Foundation, and Spanish Ministry of Economy and Competitiveness grant AGL201122783. Finally, we thank to two reviewers for their very good suggestions on the manuscript.

\section{Supplementary data}

Supplementary data related to this article can be found at http:// dx.doi.org/10.1016/j.funeco.2016.03.001.

\section{References}

Aerts, R. 1997. Climate, leaf litter chemistry and leaf litter decomposition in terrestrial ecosystems: a triangular relationship. Oikos 79, 439-449.

Austin, A.T., Vivanco, L., González-Arzac, A., Pérez, L.I., 2014. There's no place like home? an exploration of the mechanisms behind plant litter-decomposer affinity in terrestrial ecosystems. New Phytol. 204, 307-314.

Barker, D.J., Davies, E., Lane, G.A., Latch, G.C.M., Nott, H.M., Tapper, B.A., 1993. Effect of water deficit on alkaloid concentrations in perennial ryegrass endophyte associations. In: Hume, D.E., Latch, G.C.M., Easton, H.S. (Eds.), Proceedings of the 2nd International Symposium on Acremonium/Grass Interactions, pp. 67-71.

Berendse, F., Berg, B., Bosatta, E., 1987. The effect of lignin and nitrogen on the decomposition of litter in nutrient-poor ecosystems: a theoretical approach. Can. J. Bot. 65, 1116-1120.

Burns, J.C., Fisher, D.S., Rottinghaus, G.E., 2006. Grazing influences on mass, nutritive value, and persistence of stockpiled Jesup tall fescue without and with novel and wild-type fungal endophytes. Crop Sci. 46, 1898-1912.

Casas, C., Omacini, M., Montecchia, M.S., Correa, O.S., 2011. Soil microbial community responses to the fungal endophyte Neotyphodium in Italian ryegrass. Plant Soil 340, 347-355.

Chapin III, S.F., Matson, P.A., Mooney, H.A., 2002. Principles of Terrestrial Ecosystem Ecology. Springer-Verlag, New York, USA.

Clay, K., Holah, J., 1999. Fungal endophyte symbiosis and plant diversity in 
successional fields. Science 285, 1742-1744.

Clay, K., Schardl, C., 2002. Evolutionary origins and ecological consequences of endophyte symbiosis with grasses. Am. Nat. 160, S99-S127.

Clay, K., Holah, J., Rudgers, J.A., 2005. Herbivores cause a rapid increase in hereditary symbiosis and alter plant community composition. Proc. Natl. Acad. Sci. U. S. A. $102,12465-12470$.

Franzluebbers, A.J., Nazih, N., Stuedemann, J.A., Fuhrmann, J.J., Schomberg, H.H., Hartel, P.G., 1999. Soil carbon and nitrogen pools under low- and highendophyte-infected tall fescue. Soil Sci. Soc. Am. J. 63, 1687-1694.

Goering, H.K., Van Soest, P.J., 1970. Forage Fiber Analyses (Apparatus, Reagents, Procedures, and Some Applications). U.S. Agricultural Research Service.

Gundel, P.E., Omacini, M., Sadras, V.O., Ghersa, C.M., 2010. The interplay between the effectiveness of the grass-endophyte mutualism and the genetic variability of the host plant in an agronomic context. Evol. Appl. 3, 538-546.

Gundel, P.E., Hamilton, C.E., Seal, C.E., Helander, M., Martínez-Ghersa, M.A., Ghersa, C.M., Vázquez-de-Aldana, B.R., Zabalgogeazcoa, I., Saikkonen, K., 2012 Antioxidants in Festuca rubra L. seeds affected by the fungal symbiont Epichloë festucae. Symbiosis 58, 73-80.

Gundel, P.E., Garibaldi, L.A., Helander, M., Saikkonen, K., 2013a. Symbiotic interactions as drivers of trade-offs in plants: effects of fungal endophytes on tall fescue. Fungal Divers. 60, 5-14.

Gundel, P.E., Helander, M., Casas, C., Hamilton, C.E., Faeth, S.H., Saikkonen, K., 2013b. Neotyphodium fungal endophyte in tall fescue (Schedonorus phoenix): a comparison of three Northern European wild populations and the cultivar Kentucky-31. Fungal Divers. 60, 15-24.

Gundel, P.E., Helander, M., Garibaldi, L.A., Vázquez-de-Aldana, B.R. Zabalgogeazcoa, I., Saikkonen, K., 2016. Effects of Fungal Endophytes on Parameters Related with Litter Quality of Host Plants (Data in Brief, submitted).

Güsewell, S., Gessner, M.O., 2009. N: P ratios influence litter decomposition and colonization by fungi and bacteria in microcosms. Funct. Ecol. 23, 211-219.

Hall, S.J., Silver, W.L., 2013. Iron oxidation stimulates organic matter decomposition in humid tropical forest soils. Glob. Change Biol. 19, 2804-2813.

Hamilton, C.E., Gundel, P.E., Helander, M., Saikkonen, K., 2012. Endophytic mediation of reactive oxygen species and antioxidant activity in plants: a review. Fungal Divers. 54, 1-10.

Higgins, K.L., Coley, P.D., Kursar, T.A., Arnold, A.E., 2011. Culturing and direct PCR suggest prevalent host generalism among diverse fungal endophytes of tropical forest grasses. Mycologia 103, 247-260.

Hill, N.S., Rottinghaus, G.E., Agee, C.S., Schultz, L.M., 1993. Simplified sample preparation for HPLC analysis of ergovaline in tall fescue. Crop Sci. 33, 331-333.

Jia, T., Ren, A.-Z., Gao, Y.-B., 2014. Host genotype overrides endophyte infection effects on growth, physiology, and nutrient content of a native grass, Achnatherum sibiricum. Plant Ecol. 215, 875-887.

Karhu, K., Auffret, M.D., Dungait, J.A., Hopkins, D.W., Prosser, J.I., Singh, B.K. Subke, J.A., Wookey, P.A., Agren, G.I., Sebastià, M.T., Gouriveau, F., Bergkvist, G., Meir, P., Nottingham, A.T., Salinas, N., Hartley, I.P., 2014. Temperature sensitivity of soil respiration rates enhanced by microbial community response. Nature $513,81-84$.

Kumpulainen, J., Paakki, M., 1987. Analytical quality control program used by the trace elements in foods and diets sub-network of the FAO European cooperative network on trace elements. Fresenius J. Anal. Chem. 326, 684-689.

Lemons, A., Clay, K., Rudgers, J.A., 2005. Connecting plant-microbial interactions above and belowground: a fungal endophyte affects decomposition. Oecologia $145,595-604$

Lyons, P.C., Evans, J.J., Bacon, C.W., 1990. Effects of the fungal endophyte Acremonium coenophialum on nitrogen accumulation and metabolism in tall fescue. Plant Physiol. 92, 726-732.

Madritch, M.D., Hunter, M.D., 2004. Phenotypic diversity and litter chemistry affect nutrient dynamics during litter decomposition in a two species mix. Oikos 105, 125-131.

Matthews, J.W., Clay, K., 2001. Influence of fungal endophyte infection on plant/soil feedback and community interactions. Ecology 82, 500-509.

Moorhead, D., Lashermes, G., Recous, S., Bertrand, I., 2014. Interacting microbe and litter quality controls on litter decomposition: a modeling analysis. PLoS One 9, e108769.

Omacini, M., Chaneton, E.J., Ghersa, C.M., Otero, P., 2004. Do foliar endophytes affect grass litter decomposition? A microcosm approach using Lolium multiflorum. Oikos 104, 581-590.

Omacini, M., Semmartin, M.G., Perez, L.I., Gundel, P.E., 2012. Grass-endophyte symbiosis: a neglected aboveground interaction with multiple belowground consequences. Appl. Soil Ecol. 61, 273-279.

Patchett, B., Gooneratne, R., Fletcher, L., Chapman, B., 2011. Seasonal distribution of loline alkaloid concentration in meadow fescue infected with Neotyphodium uncinatum. Crop Pasture Sci. 62, 603-609.

Pinheiro, J., Bates, D., DebRoy, S., Sarkar, D., Team, R.D.C., 2014. Nlme: Linear and Nonlinear Mixed Effects Models. R Package Version 3.1-117. Retrieved from http://cran.r-project.org/package=nlme.

Purahong, W., Hyde, K.D., 2011. Effects of fungal endophytes on grass and non-grass litter decomposition rates. Fungal Divers. 47, 1-7.

R Development Core Team, 2013. R: a Language and Environment for Statistical Computing. R Foundation for Statistical Computing, Vienna, Austria.

Rasmussen, S., Parsons, A.J., Fraser, K., Xue, H., Newman, J.A., 2008. Metabolic profiles of Lolium perenne are differentially affected by nitrogen supply, carbohydrate content, and fungal endophyte infection. Plant Physiol. 146, 1440-1453.

Roberts, E.L., Ferraro, A., 2015. Rhizosphere microbiome selection by Epichloë endophytes of Festuca arundinacea. Plant \& Soil 396, 229-239.

Rodriguez, R.J., White Jr., J.F., Arnold, A.E., Redman, R.S., 2009. Fungal endophytes: diversity and functional roles. New Phytol. 182, 314-330.

Rogers, J.K., Morton, B.C., Mosali, J., 2011. Plant and endophyte effect on fiber, N, and P concentrations in tall fescue. Int. J. Agron. 2011, 1-7.

Rudgers, J.A., Fischer, S., Clay, K., 2010. Managing plant symbioses: fungal endophyte genotype alters plant community composition. J. Appl. Ecol. 47, 468-477.

Saikkonen, K., Faeth, S.H., Helander, M., Sullivan, T.J., 1998. Fungal endophytes: a continuum of interactions with host plants. Annu. Rev. Ecol. Syst. 29, 319-343.

Saikkonen, K., 2007. Forest structure and fungal endophytes. Fungal Biol. Rev. 21, 67-74.

Saikkonen, K., Gundel, P.E., Helander, M., 2013a. Chemical ecology mediated by fungal endophytes in grasses. J. Chem. Ecol. 39, 962-968.

Saikkonen, K., Ruokolainen, K., Huitu, O., Gundel, P.E., Piltti, T., Hamilton, C.E. Helander, M., 2013b. Fungal endophytes help prevent weed invasions. Agriculture. Ecosyst. Environ. 165, 1-5.

Saikkonen, K., Mikola, J., Helander, M., 2015. Endophytic phyllosphere fungi and nutrient cycling in terrestrial ecosystems. Curr. Sci. 109, 121-126.

Schardl, C.L., Grossman, R.B., Nagabhyru, P., Faulkner, J.R., Mallik, U.P., 2007. Loline alkaloids: currencies of mutualism. Phytochemistry 68, 980-996.

Siegrist, J.A., McCulley, R.L., Bush, L.P., Phillips, T.D., 2010. Alkaloids may not be responsible for endophyte-associated reductions in tall fescue decomposition rates. Funct. Ecol. 24, 460-468.

Thormann, M.N., Currah, R.S., Bayley, S.E., 2003. Succession of microfungal assemblages in decomposing peatland plants. Plant Soil 250, 323-333.

Vázquez-de-Aldana, B.R., Romo, M., García-Ciudad, A., Petisco, C., García-Criado, B. 2011. Infection with the fungal endophyte Epichloë festucae may alter the allelopathic potential of red fescue. Ann. Appl. Biol. 159, 281-290.

Vázquez-de-Aldana, B.R., García-Ciudad, A., García-Criado, B., Vicente-Tavera, S. Zabalgogeazcoa, I., 2013a. Fungal endophyte (Epichloë festucae) alters the nutrient content of Festuca rubra regardless of water availability. PLoS ONE 8, e84539.

Vázquez-de-Aldana, B.R., Bills, G., Zabalgogeazcoa, I., 2013b. Are endophytes an important link between airborne spores and allergen exposure? Fungal Divers. $60,33-42$

Wardle, D.A., Bardgett, R.D., Klironomos, J.N., Setälä, H., van der Putten, W.H., Wall, D.H., 2004. Ecological linkages between aboveground and belowground biota. Science 304, 1629-1633.

White Jr., J.F., Torres, M.S., 2010. Is plant endophyte-mediated defensive mutualism the result of oxidative stress protection? Physiol. Plant. 138, 440-446.

Wieder, R.K., Lang, G.E., 1982. A critique of the analytical methods used in examining decomposition data obtained from litter hags. Ecology 63, 1636-1642.

Yue, Q., Logendra, S., Freehoff, A., Richardson, M.D., 1997. Alkaloids of turf-type fine fescue (Festuca Sp.). In: Bacon, C.W., Hill, N.S. (Eds.), Neotyphodium/Grass Interactions, pp. 285-287.

Yue, Q. Jonson-Cicalese, J., Gianfagna, TJ., Meyer, W.A., 2000. Alkaloid production and chinch bug resistance in endophyte-inoculated chewings and strong creeping red fescues. J. Chem. Ecol. 26, 279-292.

Zabalgogeazcoa, I., Gundel, P.E., Helander, M., Saikkonen, K., 2013. Non-systemic fungal endophytes in Festuca rubra plants infected by Epichloë festucae in subarctic habitats. Fungal Divers. 60, 25-32.

Zhang, D., Hui, D., Luo, Y., Zhou, G., 2008. Rates of litter decomposition in terrestrial ecosystems: global patterns and controlling factors. J. Plant Ecol. 1, 85-93. 